Proc. Estonian Acad. Sci. Geol., 2004, 53, 4, 257-266

\title{
The earliest known Trypanites borings in the shells of articulate brachiopods from the Arenig (Ordovician) of Baltica
}

\author{
Olev Vinn \\ Institute of Geology, University of Tartu, Vanemuise 46, 51014 Tartu, Estonia; vinn@ut.ee \\ Received 7 November 2003, in revised form 19 March 2004
}

\begin{abstract}
Several specimens of the Arenig (Volkhov Stage) brachiopod Antigonambonites from Northwest Russia and North Estonia bear the earliest known Trypanites borings in articulate brachiopod shells. Two basic types of borings are recorded: rare large rounded borings that penetrate the shell of the brachiopod, and abundant borings that follow the shell, almost never intersecting it. Rare shell repair marks are associated with some Trypanites borings. Presumably some shell-boring worms inhabited also the living Antigonambonites brachiopods, suggesting that diverse shell boring strategies had evidently evolved by the Arenig.
\end{abstract}

Key words: Trypanites, shell borings, brachiopods, palaeoecology, Arenig, Northwest Russia, North Estonia.

\section{INTRODUCTION}

The goal of the present research is to describe for the first time the oldest known presumable commensal worm borings in the shells of articulate brachiopods. The paper deals with different morphologies of Trypanites and Trypanites-like borings in the brachiopods from the early Ordovician of the Baltoscandian basin, with some brief comparison to the other Lower Palaeozoic basins as well as modern environment.

The oldest macroborings in the world are Lower Cambrian Trypanites, which are small, simple borings that have been reported from archeocyathid reefs in Labrador (James et al. 1977; Kobluk et al. 1978). Essentially no macroborings are known throughout the rest of the Cambrian Period. The next oldest macroborings reported are from carbonate hardgrounds of Early Ordovician age (Palmer \& Plewes 1993; Ekdale \& Bromley 2001). 


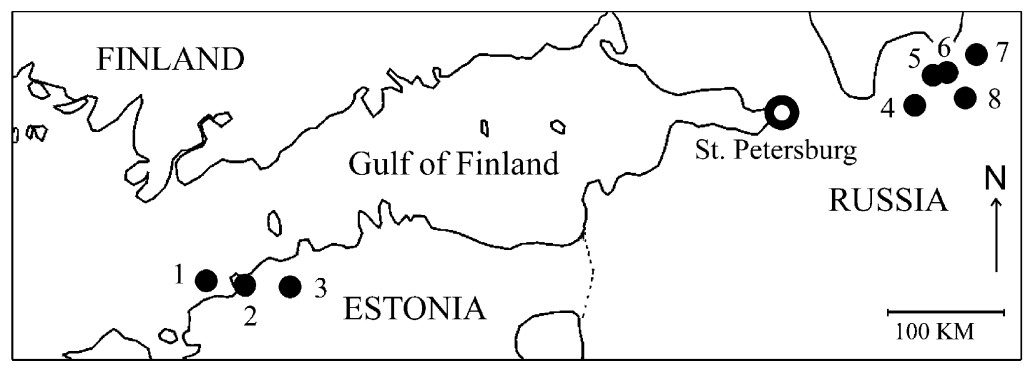

Fig. 1. Map showing geographic occurrences of Antigonambonites brachiopods (Arenig, Volkhov Stage) with Trypanites borings in North Estonia and the Leningrad Region, Northwest Russia. Localities of Trypanites borings indicated by dots with adjacent numbers. The numbered sections are: 1, Väike-Pakri; 2, Paldiski; 3, Mäeküla; 4, Lava; 5, Volkhov; 6, Gornaya Sheldina; 7, Syas; 8, Lynna.

The oldest Trypanites borings in shells were previously known from the Middle Ordovician Trentonian Series (Mägdefrau 1932; Cameron 1969). Abundant in the Devonian, the Trypanites (= Vermiforichnus) trace fossils are known from the Dinorthis brachiopod community of central Wales (Pickerill 1976). In Baltoscandia, worm borings in Ordovician brachiopods have been recorded from the Mjösa Limestone of southern Norway, although Trypanites (= Vermiforichnus) borings in brachiopods are very rare. The Mjösa Limestone formed during the middle Late Ordovician (Late Caradoc) at the western margin of the extensive early Palaeozoic epicontinental sea of Baltoscandia (Opalinski \& Harland 1980).

Abundant worm borings occur also in brachiopods from the Estonian oil shale (Fig. 1). These are slightly older in age (Caradoc, Kukruse Age; Fig. 2) than those described from Wales and Norway, but resemble closely Trypanites (author's personal observations).

In contrast to possible worm borings in shells, Lower Ordovician endolithic microborings of algal, fungal, and sponge origin are well known from northern Poland (Podhalanska 1984), and the Siljan District of Sweden (Hessland 1949; Lindström 1979). Such endolithic borings, found in trilobite carapaces and mollusc shells, are abundant in Lower Ordovician limestones of the Central Baltoscandian confacies belt (Olempska 1986). The limestones of the Central Baltoscandian confacies belt are shallow-water deposits formed within the photic zone. In contrast, Lindström (1988) argued for deeper depositional conditions in the order of several hundred metres.

In the Baltic oil shale (Kukruse Stage, Caradoc) probable worm borings are known from bryozoan colonies in the Leningrad Region in NW Russia (Fig. 1). These borings were originally identified by Hecker as Hicetes (Hecker 1928), but they closely resemble Trypanites weisei as figured by Bromley (1972).

Recently, shell borings closely resembling those of Trypanites were discovered in the Arenig brachiopod Antigonambonites from Baltica. The oldest known material was collected from strata of the Volkhov Stage in the Leningrad 


\begin{tabular}{|c|c|c|}
\hline \multicolumn{2}{|c|}{$\begin{array}{c}\text { GLOBAL/BRITISH } \\
\text { SERIES }\end{array}$} & BALTIC STAGES \\
\hline \multirow{8}{*}{$\begin{array}{l}\frac{r}{山} \\
\frac{0}{2} \\
\frac{0}{2}\end{array}$} & \multirow{2}{*}{ ASHGILL } & PORKUNI \\
\hline & & $\frac{\text { PIRGU }}{\text { VORMSI }}$ \\
\hline & \multirow{6}{*}{ CARADOC } & NABALA \\
\hline & & RAKVERE \\
\hline & & OANDU \\
\hline & & KEILA \\
\hline & & HALJALA \\
\hline & & KUKRUSE \\
\hline \multirow{5}{*}{$\begin{array}{l}\stackrel{\uplus}{\vec{\partial}} \\
\stackrel{\alpha}{\Sigma}\end{array}$} & \multirow{4}{*}{ LLANVIRN } & UHAKU \\
\hline & & LASNAMÄGI \\
\hline & & ASERI \\
\hline & & KUNDA \\
\hline & \multirow{3}{*}{ ARENIG } & VOLKHOV \\
\hline \multirow{3}{*}{ 絿 } & & BILLINGEN \\
\hline & & HUNNEBERG \\
\hline & TREMADOC & $\begin{array}{l}\text { VARANGU } \\
\text { PAKERORT }\end{array}$ \\
\hline
\end{tabular}

Fig. 2. Stratigraphical subdivisions of the Baltoscandian Ordovician.

Region of Northwest Russia and North Estonia. Lower and lowermost Middle Ordovician rocks in that area represent a condensed sequence, resulting from slow sedimentation in a relatively shallow epicontinental sea that was starved of siliciclastic sediments (Jaanusson 1973). During the Arenig, the Baltic craton was positioned approximately 60 degrees south of the equator, and the area experienced a temperate climate (Torsvik 1998).

\section{MATERIAL AND METHODS}

Antigonambonites planus is a finely costate, biconvex to slightly convexoconcave, relatively large and thick-shelled polytoechiid brachiopod, without a functional pedicle (Popov et al. 2001), which has previously been classified as a clitambonitid (Rubel \& Wright 2000). The Antigonambonites specimens yielding Trypanites borings were collected from the strata of the Volkhov Stage (Arenig) of the Baltic Basin (see Figs. 1 and 2). Most specimens were collected from the clay intercalations of limestone beds. The specimens from the clay intercalations were easily cleaned from sediment using a toothbrush and water. The collection of Antigonambonites valves from eight different localities in North Estonia and Northwest Russia (Table 1) yielded 34 specimens with Trypanites borings out of a total of 199 valves (76 dorsal and 123 ventral valves) studied. The whole collection of Antigonambonites contains $61.8 \%$ slightly thicker and more resistant ventral valves, and $38.2 \%$ thinner and weaker dorsal valves. The borings are preserved in the form of tubular carbonate sediment fillings within the calcitic brachiopod shell. Shell thickness of the adult Antigonambonites in the collection 
Table 1. List of localities of Antigonambonites with Trypanites borings and its boring rates

\begin{tabular}{l|c|c|c}
\hline \multicolumn{1}{c|}{ Locality } & $\begin{array}{c}\text { Number of } \\
\text { studied valves }\end{array}$ & $\begin{array}{c}\text { Number of } \\
\text { bored valves }\end{array}$ & $\begin{array}{c}\text { Boring rate, } \\
\%\end{array}$ \\
\hline Väike Pakri, NW Estonia & 10 & 0 & 0 \\
Paldiski, NW Estonia & 8 & 1 & 12.5 \\
Mäeküla, NW Estonia & 15 & 0 & 0 \\
Lava River, Russia & 45 & 4 & 8.8 \\
Volkhov River, Russia & 64 & 17 & 26.6 \\
Lynna River, Russia & 19 & 3 & 15.8 \\
Syas River, Russia & 12 & 5 & 41.7 \\
Gornaya Sheldina, Russia & 26 & 4 & 15.4
\end{tabular}

varies between 0.3 and $3.0 \mathrm{~mm}$. The average shell width is $1.3-35 \mathrm{~mm}$ and length $8.0-26 \mathrm{~mm}$. The average boring frequency for Antigonambonites planus is $17.1 \%$ (Table 1). The smallest valve with borings is $10 \mathrm{~mm}$ long and $1.3 \mathrm{~mm}$ wide; in the smaller 26 valves throughout the whole collection no shell borings have been found.

Unfortunately, it is not possible to produce the resin casts enabling determination of the exact nature of these borings, because of the hard carbonate filling of borings surrounded by the carbonate matrix. All the studied specimens of Antigonambonites with borings are deposited at the Museum of Geology, University of Tartu.

\section{RESULTS}

Two main types of Trypanites borings have been identified. The first type includes small borings that are oriented sub-parallel to parallel to the surface of the valve, but that rarely intersect the valve. Borings of the second, less common type have a larger diameter and penetrate valves almost at 90 degrees. Incomplete boring marks occur rarely on the exteriors of Antigonambonites. "Blister"-like repair structures have been observed in association with some borings.

\section{The Trypanites borings}

The Trypanites borings consist of elongate, cylindrical shafts that are circular in cross section; their terminations are rounded (Fig. 3.4, 3.6, 3.7). They range in diameter from 0.2 to $1.1 \mathrm{~mm}$ (mean $0.5 \mathrm{~mm}$ ) and may be as long as $14 \mathrm{~mm}$ (Fig. 4). The shafts are commonly straight to slightly curved, more rarely sinusoidal or hooked, but may be oval or flattened.

Several borings differ slightly in shape from the original definition of Trypanites. A single boring is obviously U-shaped, with both terminations in the external surface of Antigonambonites (Fig. 5.1). 


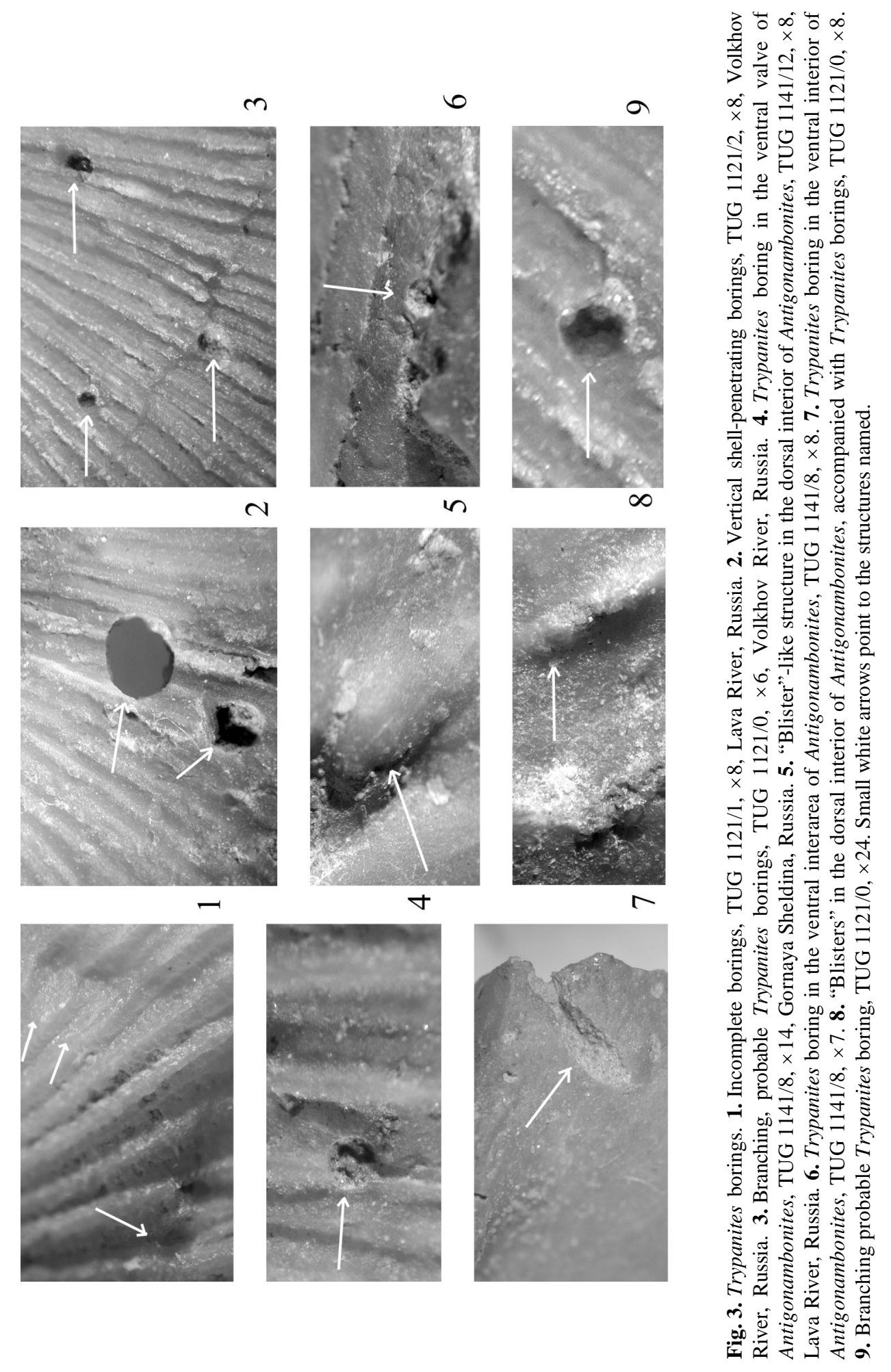




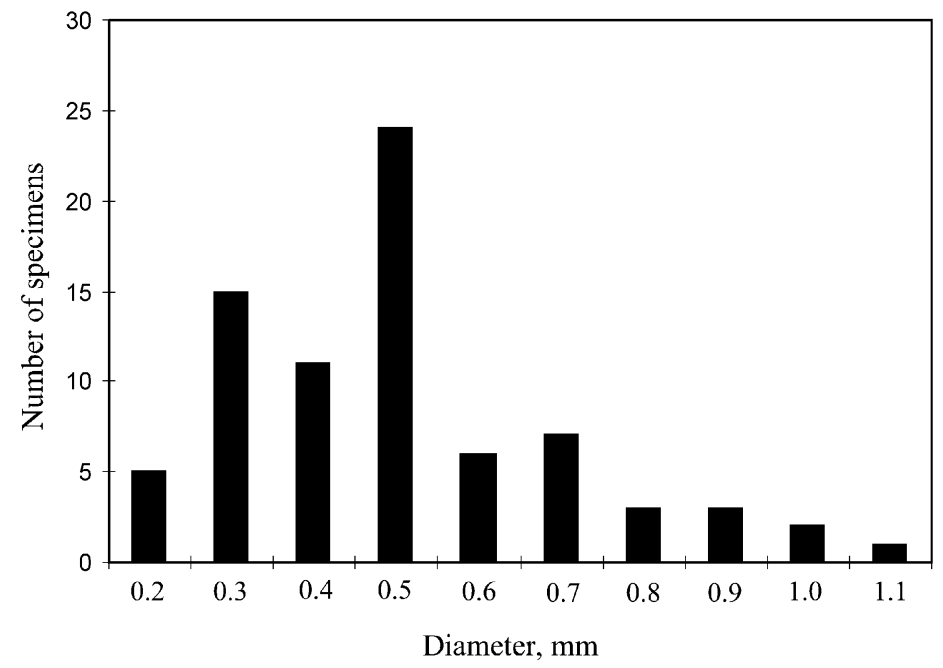

Fig. 4. Frequency histogram of the maximum diameter of the studied 76 Trypanites borings in the shell of Antigonambonites.

Four borings are clearly multitunnelled (their diameters are $0.3,0.3,0.4$, and $0.5 \mathrm{~mm}$ ), while two, have more than one aperture in the external valve surface of the host (Figs. 3.3, 3.9; 5.3). Whether the multitunnelled borings constitute a true branching boring system, or whether they are abandoned tunnels from which a sessile worm has drawn back, could not be determined. The histogram (Fig. 4) of maximum diameters of all probable Trypanites borings described in Antigonambonites resembles closely the histogram of the maximum diameter of Trypanites (= Vermiforichnus) from the Late Ordovician of Ohio (Cameron 1969, p. 697, fig. 5c). However, it is possible that the rare multitunnelled borings, and perhaps those that are U-shaped, were created by another "taxon".
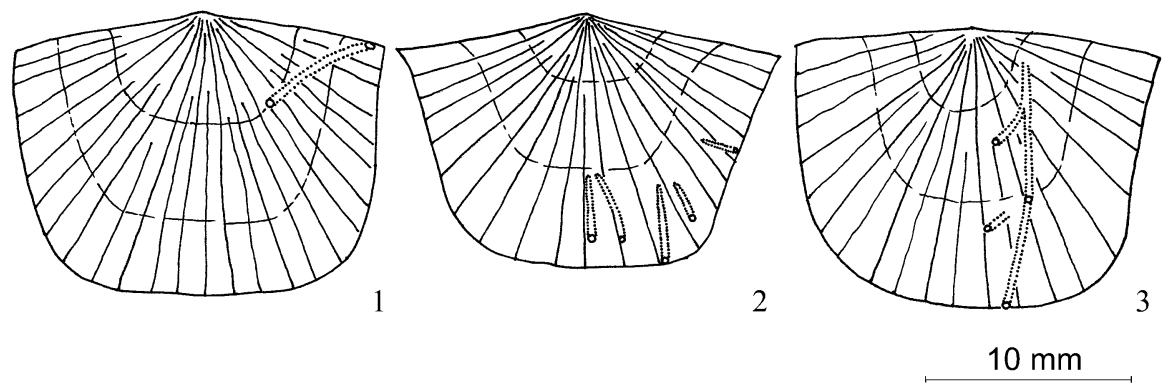

Fig. 5. Generalized drawings of the worm borings in Antigonambonites shells. 1. U-shaped probable Trypanites boring, TUG 1141/11. 2. Orientated Trypanites borings at the anterior commissure of the ventral valve in Antigonambonites planus, TUG 1141/1. 3. Multitunnelled probable Trypanites borings in the dorsal valve of Antigonambonites, TUG 1141/7. 
Two large, oval to rounded borings, $1-1.8 \mathrm{~mm}$ in diameter, penetrate the shell, almost perpendicularly to the valve surface. The hole apertures are sharp and as wide as the diameter of the boring at depth. These borings are two and three times as large as the shell thickness at the boring site, respectively (Fig. 3.2).

\section{Incomplete borings}

Relatively small pits of different depth, 0.4 to $0.6 \mathrm{~mm}$ in diameter, usually wider than deep, occur in the exterior of Antigonambonites (Fig. 3.1). Several similar marks are located near each other on the same valve. These marks could be the ends of probable vertical borings made by borers into the hardened sediment (see the discussion on large borings above), but it is unlikely because all "failed" borings terminate in the thin parts of the valve, while the thick anterior part of the same valve accommodates three successful Trypanites borings. Presumably these unfinished borings were made by a too large worm, which failed to create a domicile because the shell was too thin (about two times thinner than the maximum diameter of the boring). This suggests that the boring organisms were able to select actively the boring site on living brachiopods.

\section{Shell repair marks}

"Blister"-like elevated structures occur sometimes in the valve interiors and are associated with borings that occur very close to the shell interior surface (Fig. 3.8). These structures are evidently the reaction of the living brachiopod to the disturbance caused by the boring organism. The relatively small number of such repair structures indicates that the relationship between the shell-boring commensal worm and its host was potentially damaging. A few clearly "blister"like structures are found in the interiors of Antigonambonites, which do not associate with any particular boring (Fig. 3.5). They were either produced in reaction to some unknown intruder in the living shell or represent completely repaired borings. However, as there is no sign of the repaired boring apertures on the external side of the valves, it is more likely that these "blisters" are not directly associated with the worm borings.

\section{THE NATURE OF EARLY SHELL BORINGS IN ANTIGONAMBONITES}

With respect to ecology the borings in Antigonambonites may represent two different types. The large penetrating holes in brachiopods were possibly produced by worms subsequent to deposition. They occasionally penetrated the dead brachiopod valves in the bottom sediment (Richards \& Shabica 1969). These borings are evidence of the ability of these infaunal worms to bore into the 
calcareous substrates, but they are presumably not specific to any kind of shells as the substratum. However, without comprehensive statistical analyses of the taphocoenosis, the predatory origin of these borings cannot be excluded, as it has been suggested for some borings in Richmondian Onniella meeki (see Kaplan \& Baumiller 2000).

The second type of borings has several adaptive characters for life within the brachiopod (alive or dead) shell. Several characters of the shell borers have been regarded to have adaptive importance, such as the ability to avoid intersections of the valve surfaces and the other borings; concentration on large hosts (see Thayer 1974 , p. 885), and the orientation of borings for taking advantage of feeding currents of the living host (see Pickerill 1976, pp. 161, 162, fig. 1b). The borings of commensal living annelids (Boekschoten 1966) are parallel to the surfaces of valve, and almost never intersect them. The presence of oriented Trypanites at the anterior of the commissure of brachiopods, as well as their higher number on dorsal valves, are features clearly specific to living brachiopods (see Thayer 1974; Pickerill 1976).

The borings in Antigonambonites are size specific. The average boring frequency in the studied collection is $17 \%$ (Table 1), while the valves smaller than $13 \mathrm{~mm}$ (26) are lacking the borings. The frequency of borings in dorsal valves is $22.4 \%$ (76 valves studied) versus $15.4 \%$ in ventral valves (123 valves studied), presumably due to the suggested initial living orientation of all articulates with the dorsal valve upwards. This suggests that the borer mostly infected living brachiopods. The boring intensity of the bored ventral and dorsal valves of Antigonambonites is almost equal (2.4 borings per valve). A few valves of Antigonambonites also bear clearly oriented borings (Fig. 5.2) at the anterior commissure of valve. A majority of the valves $(96.5 \%)$ bear only the external borings, while the boring frequency in shell interiors is $3.5 \%$ of all bored valves, suggesting borer's strong preference for living brachiopods. However, it is possible that in the living position the ventral valve of adult Antigonambonites was partially exposed to the water column.

Kobluk et al. (1978) suggested that the initial diversification of macroboring organisms was related to the development of skeletal reefs in the Middle Ordovician. However, diverse shell-boring strategies had evidently evolved by the Arenig. The niche specialization of shell-boring worms may well be associated with the appearance of large calcitic brachiopods in shallow-water facies in the Late Cambrian. Monge-Najera et al. (2000) established an alternative model for early Palaeozoic marine ecological community structure. They argued that a mature ecological community structure was generalized during the Cambrian, and even biodiversity was surprisingly close to modern values. This model may well explain the presence of diverse shell borings already in the Arenig, before the extensive distribution of skeletal reefs in the late Middle Ordovician. The diverse nature of worm borings in Antigonambonites in the Arenig of Baltoscandia could be explained either by flexibility in the behaviour of the borer as with the modern Polydora (see Boekschoten 1966), or by high taxonomic diversity. 


\section{ACKNOWLEDGEMENTS}

I am grateful to Prof. Tim Palmer for constructive comments on the manuscript. I would like to thank Dr. Patricia Kelley and Dr. Mikael Calner for the critical reading of the manuscript and for linguistic corrections. This research was supported by grant TBGGL 0550: "Sedimentology and Palaeontology of the Baltoscandian sedimentary cover", main research theme at the Institute of Geology, University of Tartu, and by the Estonian Science Foundation (grant No. 5290).

\section{REFERENCES}

Boekschoten, G. J. 1966. Shell borings of sessile epibiontic organisms as palaeoecological guides. Palaeogeogr. Palaeoclimatol. Palaeoecol., 3, 311-362.

Bromley, R. G. 1972. On some ichnotaxa in hard substrates, with a redefinition of Trypanites Magdefrau. Paläontol. Z., 46, 93-98.

Cameron, B. 1969. Palaeozoic shell-boring annelids and their trace fossils. Amer. Zoologist, 9, 689703.

Ekdale, A. A. \& Bromley, R. G. 2001. Bioerosional innovation for living in carbonate hardgrounds in the Early Ordovician of Sweden. Lethaia, 34, 1-12.

Hecker, R. 1928. Palaeobiological study of Lower Silurian invertebrates, I. Yezhegodnik Russkogo Paleontologicheskogo Obshchestva, T. VII (1927), 1-86 (in Russian).

Hessland, I. 1949. Investigation of the Lower Ordovician of the Siljan District, Sweden, II. Lower Ordovician penetrative and enveloping algae from the Siljan District. Bull. Geol. Inst. Univ. Uppsala, 33, 409-429.

Jaanusson, V. 1973. Aspects of carbonate sedimentation in the Ordovician of Baltoscandia. Lethaia, 6, 11-34.

James, N. P., Kobluk, D. R. \& Pemberton, S. G. 1977. The oldest macroborers: Lower Cambrian of Labrador. Science, 197, 980-983.

Kaplan, P. \& Baumiller, K. T. 2000. Taphonomic inferences on boring habit in the Richmondian Onniella meeki Epibole. Palaios, 15, 6.

Kobluk, D. R., James, N. P. \& Pemberton, S. G. 1978. Initial diversification of macroboring ichnofossils and exploitation of the macroboring niche in the lower Paleozoic. Paleobiology, 4, 163-170.

Lindström, M. 1979. Probable sponge borings in Lower Ordovician limestone of Sweden. Geology, 7, 152-155.

Lindström, M. 1988. Ordovician palaeotopography in Baltoscandia. In 18th Nordic Geological Winter Meeting, Abstracts (Binzer, K., Marcussen, I. \& Konradi, P., eds.), p. 261. Copenhagen.

Mägdefrau, K. 1932. Über einige Bohrgänge aus dem unteren Muschelkalk von Jena. Paläontol. Z., 14, 150-160.

Monge-Najera, J., Hou, Xianguang \& Vargas, J. A. 2000. Disparity, decimation and the Cambrian "explosion": comparison of early Cambrian and Present faunal communities with emphasis on velvet worms (Onychophora). Rev. Biol. Trop., 48, 333-351.

Olempska, E. 1986. Endolithic microorganisms in Ordovician ostracod valves. Palaeontol. Polonica, 31, 229-236.

Opalinski, P. R. \& Harland, T. L. 1980. Macroborings of Middle Ordovician age from southern Norway. J. Paleontol., 54, 1352-1355.

Palmer, T. J. \& Plewes, C. R. 1993. Borings and bioerosion in the fossil record. Geol. Today, 9 , $138-142$. 
Pickerill, R. K. 1976. Vermiforichnus borings from the Ordovician of Central Wales. Geol. Mag., 113, 159-164.

Podhalanska, T. 1984. Microboring assemblage in Lower/Middle Ordovician limestones from northern Poland. Neues Jahrb. Geol. Paläontol. Monatsh., 8, 497-511.

Popov, L. E., Vinn, O. \& Nikitina, O. I. 2001. Brachiopods of the redefined family Tritoechiidae from the Ordovician of Kazakhstan and South Urals. Geobios, 34, 131-155.

Richards, R. P. \& Shabica, C. W. 1969. Cylindrical living burrows in Ordovician Dalmanellid brachiopod beds. J. Paleontol., 43, 838-841.

Rubel, M. \& Wright, A. D. 2000. Clitambonitidina. In Treatise on Invertebrate Paleontology, Part H, Brachiopoda 3 (Kaesler, R., ed.), pp. 692-708. Geological Society of America and University of Kansas Press, Lawrence, Kansas.

Thayer, C. W. 1974. Substrate specificity of Devonian epizoa. J. Paleontol., 48, 881-894.

Torsvik, T. H. 1998. Palaeozoic paleogeography: a North Atlantic viewpoint. GFF, 120, 109-118.

\section{Vanimad Trypanites'e ussikäigud Balti Arenigi (Ordoviitsiumi) lukuliste käsijalgsete karbikaantes}

\section{Olev Vinn}

Vanimad Trypanites'e ussikäigud käsijalgsete karbikaantes pärinevad PõhjaEesti ja Loode-Venemaaa Volhovi lademest. Nimetatud ussikäigud jagunevad üldjoontes kahte tüüpi: harvad laiad karbikaant läbistavad augud ja arvukad karbikaane sees kulgevad käigud. Lisaks esineb Antigonambonites'el ka haruldasi karbi paranemisstruktuure, mis viitavad võimalusele, et osa käike oli uuristatud elus isendite poolmetesse. 